\title{
Pemanfaatan Limbah Spent Bleaching Earth pada Stabilisasi Tanah Lempung dengan Clean Set Cement
}

\section{Utilization of Spent Bleaching Earth Waste on Clay Stabilization Using Clean Set Cement}

\author{
AGUNG SUMARNO, AGUS MUDO PRASETYO, FAZHAR AKBAR, EKO WIDODO, TRIASTUTI, \\ MAIDINA, ANANTO NUGROHO, ISMAIL BUDIMAN, BAMBANG SUBIYANTO
}

Pusat Penelitian Biomaterial, Lembaga llmu Pengetahuan Indonesia, Jl. Raya Bogor Km.46 Cibinong, Bogor 16911. e-mail : agung.ayahshofiyya@gmail.com

\begin{abstract}
The utilization of waste as soil stabilization materials is a solution to reduce the amount of waste and improve the building materials quality. This research is using Spent Bleaching Earth (SBE) materials from the palm oil industry waste. SBE can be reused to be pozzolan materials. This research aimed to investigate the SBE waste effect as an admixture on clay stabilization used $10 \%$ Clean Set Cements (CS60) on density and California Bearing Ratio (CBR). A combination of CS-60 and SBE waste was expected to increase the CBR value of clay. Furthermore, SBE waste would decrease cementitious material for clay stabilization. Variation comparison of Clay : CS-60 : SBE on ST03, ST04, and ST05 were 67.5\% : $10 \%: 22.5 \% ; 45 \%: 10 \%: 45 \%$ and $22.5 \%: 10 \%: 67.5 \%$ respectively. The test was conducted on water content, density, and load penetration based on SNI 1744:2012. Generally, the CBR value of subgrade and improved subgrades oil with the moderate and good category are about $5-20 \%$. As a result, the CBR value of ST 01 as original clay and ST 02 as clay with $10 \%$ CS-60 was $3.24 \%$ and $5.01 \%$, respectively. Using SBE waste as an admixture material on clay stabilization increased CBR value better than clay stabilization used CS-60. ST03, ST04, and STO5 with CBR's value were 5.39\%, 8.52\%, and 17.99\%, respectively. Furthermore, the density value decreased when SBE waste is used.
\end{abstract}

Keywords : california bearing ratio, clay, clean set cement, spent bleaching earth, stabilization.

\begin{abstract}
ABSTRAK
Pemanfaatan limbah sebagai bahan stabilisasi tanah lempung merupakan solusi dalam mengurangi jumlah limbah dan meningkatkan mutu dari bahan bangunan. Penelitian ini menggunakan material Spent Bleaching Earth (SBE) dari limbah industri pengolahan minyak kelapa sawit. SBE dapat dimanfaatkan sebagai material pozzolan. Penelitian ini bertujuan untuk mengetahui pengaruh limbah SBE sebagai bahan tambah pada stabilisasi tanah lempung yang menggunakan $10 \%$ Clean Set Cements (CS-60) terhadap densitas dan California Bearing Ratio (CBR). Kombinasi limbah SBE dengan CS-60 diharapkan mampu meningkatkan nilai CBR tanah lempung. Selain itu, juga mengurangi penggunaan bahan berbasis semen untuk stabilisasi tanah lempung. Variasi perbandingan tanah lempung : CS-60 : SBE yang digunakan pada sampel ST03, ST04, dan ST05 berturut-turut $67,5 \%: 10 \%: 22,5 \%, 45 \%: 10 \%$ : $45 \%$ dan 22,5\%:10\%:67,5\%. Pengujian yang dilakukan meliputi pengujian kadar air, densitas, dan penetrasi beban yang mengacu pada SNI 1744:2012. Secara umum, nilai CBR tanah dasar dan tanah timbunan dengan kategori sedang dan baik berkisar antara $5-20 \%$. Hasil penelitian ini memperlihatkan bahwa sampel ST01 yang berupa tanah lempung asli memiliki nilai CBR 3,24\% dan sampel ST02 yang berupa tanah lempung yang distabilisasi dengan 10\% CS-60 menghasilkan nilai CBR 5,01\%. Penambahan limbah SBE dapat meningkatkan nilai CBR dengan nilai yang lebih tinggi bila dibanding dengan hanya distabilisasi dengan CS-60, hal ini terlihat pada sampel ST03, ST04, dan ST05 dengan nilai CBR berurutan sebesar 5,39\%, 8,52\%, dan 17,99\%. Selain itu, penambahan limbah SBE juga akan menurunkan densitas dari tanah lempung.
\end{abstract}

Kata kunci : california bearing ratio, clean set cement, spent bleaching earth, stabilisasi, tanah lempung.

\section{PENDAHULUAN}

\subsection{Latar Belakang}

Pertumbuhan pembangunan infrastruktur di Indonesia sangat pesat terutama pembangunan jalan dan perumahan. Kualitas jalan dan lahan perumahan akan baik apabila didukung oleh kondisi tanah dasar yang baik pula. Untuk itu stabilisasi tanah dasar perlu dilakukan untuk memastikan kualitas tanah dalam mendukung jenis perkerasan yang akan dibangun, baik itu perkerasan lentur maupun perkerasan kaku. Salah satu indikator daya dukung tanah adalah nilai California Bearing Ratio (CBR), di mana 
semakin baik nilai CBR tanah dasar maka semakin baik pula daya dukung tanah tersebut.

Berbagai penelitian telah dilakukan untuk meningkatkan nilai CBR tanah. Upaya peningkatan CBR tanah dapat dilakukan dengan beberapa metode diantaranya secara mekanis dengan pemadatan maupun kimiawi dengan penambahan semen Portland atau bahan berbasis semen $^{(1)}$. Bahan berbasis semen yang biasa digunakan adalah CS-60 untuk memperbaiki stabilitas dan karakteristik tanah dasar $^{(2)}$

Selain menggunakan bahan berbasis semen, beberapa penelitian juga menggunakan bahan berbasis limbah untuk stabilisasi tanah dasar. Di antaranya adalah pemanfaatan fly $a s h^{(3)}$ dan abu sekam padi ${ }^{(4)}$ sebagai bahan aditif untuk stabilisasi pada tanah dasar. Pemanfaatan limbah pada stabilisasi tanah dasar akan mengurangi penggunaan bahan berbasis semen sehingga menjadikan pembangunan infrastruktur jalan yang ramah lingkungan. Pada penelitian terdahulu limbah SBE dimanfaatkan sebagai material bangunan seperti bata tanpa pembakaran, di mana hasil yang diperoleh menunjukkan bahwa SBE dapat menggantikan hingga $25 \%$ pasir pada pembuatan bata tanpa pembakaran dengan komposisi material pasir, semen, tanah laterit, dan $\mathrm{SBE}^{(5)}$. Dalam penelitian lain yang menggunakan SBE sebagai material dalam pembuatan bata beton juga menunjukkan bahwa SBE dapat digunakan untuk menggantikan agregat halus hingga $50 \%$ dengan kekuatan tidak kurang dari 2,5 MPa dan memenuhi persyaratan kekuatan bata beton oleh SNI 03-0349-1989 ${ }^{(6)}$.

Pada penelitian ini, dilakukan eksperimen dengan memanfaatkan limbah SBE. SBE adalah limbah padat pada industri pemurnian minyak kelapa sawit ${ }^{(7)}$. Bleaching Earth (BE) yang merupakan lempung (clay) berjenis simnite atau bentonite yang telah diputihkan dan diaktivasi selanjutnya digunakan untuk memurnikan minyak mentah ${ }^{(8)}$, dan setelah berkurangnya kemampuan penyerapan karena kandungan minyak di dalamnya $20-30 \%$ BE tidak terpakai lagi dan dibuang menjadi limbah $\mathrm{SBE}^{(9)}$. Upaya pemisahan minyak dari padatan clay pada SBE ini sangat sulit dilakukan, salah satunya dengan pelarut aseton untuk mendapatkan recovery minyak yang dapat dimanfaatkan lagi sebagai bahan bakar terbarukan ${ }^{(10)}$. Karena proses yang sangat sulit ini maka perlu dicari solusi untuk memanfaatkan SBE secara langsung, salah satunya adalah dengan mencampur bersama semen sehingga mengeras dan menjadikannya sebagai material bangunan. SBE memiliki potensi yang sangat besar untuk dijadikan material bangunan semisal beton, hal ini dikarenakan ketersediannya yang sangat banyak sejumlah 737,19 ton dalam satu bulan dari satu perusahaan pengolahan minyak kelapa sawit yaitu PT. SMART Tbk. dan apabila dijadikan sebagai agregat halus untuk material bangunan dapat diserap sejumlah $220 \mathrm{~kg}$ dalam tiap satu kubik campuran beton ${ }^{(11)}$.

Dengan potensi ketersediaan limbah SBE yang sangat banyak dan juga penelitian terdahulu yang memanfaatkan SBE sebagai bahan bangunan, mendorong penelitian yang memanfaatkan limbah SBE untuk stabilisasi tanah dasar. Limbah SBE dapat dijadikan material pozzolan ${ }^{(12)}$ sehingga memungkinkan untuk dapat dijadikan material stabilisasi tanah dan juga penyerapannya dalam pemanfaatan kembali limbah akan lebih besar. Oleh karena itu, penelitian ini memanfaatkan limbah SBE sebagai bahan stabilisasi tanah dasar yang jenisnya lempung (clay) menggunakan CS-60 dengan harapan dapat meningkatkan nilai CBR.

\subsection{Tujuan Penelitian}

Tujuan dari penelitian ini adalah mengetahui pengaruh penggunaan limbah SBE dan CS-60 dengan berbagai komposisi terhadap densitas dan nilai CBR.

\section{BAHAN DAN METODE}

\subsection{Bahan}

Tanah lempung yang digunakan berasal dari kawasan industri MM2100 Bekasi-Jawa Barat sebagai sampel kontrol ST01, kemudian distabilisasi dengan menggunakan CS-60 dengan perbandingan tanah lempung : CS-60 $90 \%$ : $10 \%$ sebagai sampel ST02. Selanjutnya dikombinasikan dengan limbah SBE yang berasal dari industri pengolahan minyak kelapa sawit PT. SMART Tbk. sebagai sampel ST03, ST04 dan ST05 dengan perbandingan tanah lempung, CS-60, SBE berturut-turut adalah $67,5 \%, 10 \%, 22,5 \% ; 45 \%, 10 \%, 45 \%$, dan $22,5 \%, 10 \%, 67,5 \%$. Variasi sampel disajikan pada Tabel 1.

Tabel 1. Variasi sampel

\begin{tabular}{lccc}
\hline \multirow{2}{*}{ Kode } & \multicolumn{3}{c}{ Komposisi } \\
\cline { 2 - 4 } & $\begin{array}{c}\text { Tanah Lempung } \\
(\%)\end{array}$ & $\begin{array}{c}\text { CS-60 } \\
(\%)\end{array}$ & $\begin{array}{c}\text { SBE } \\
(\%)\end{array}$ \\
\hline ST01 (Kontrol) & 100 & - & - \\
ST02 & 90 & 10 & - \\
ST03 & 67,5 & 10 & 22,5 \\
ST04 & 45 & 10 & 45 \\
ST05 & 22,5 & 10 & 67,5 \\
\hline
\end{tabular}

Analisis saringan dilakukan terhadap tanah lempung yang digunakan, dan hasil menunjukkan sebesar $55,12 \%$ lolos saringan $0,074 \mathrm{~mm}$ (No. 200). Sesuai dengan standar 
USCS tergolong tanah berbutir halus karena lebih dari $50 \%$ lolos saringan No. 200. Hasil analisis saringan disajikan pada Gambar 1.

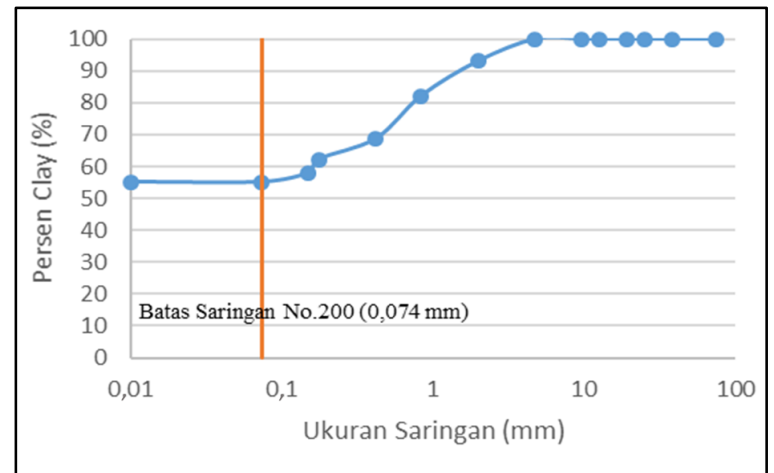

Gambar 1. Analisis Saringan Tanah Lempung (clay)

\subsection{Metode}

Penelitian ini dilakukan dengan cara eksperimental untuk mendapatkan nilai CBR di laboratorium $^{(13)}$. CBR ditentukan berdasar pada SNI 1744 : 2012, sehingga terlebih dahulu dilakukan pengujian kadar air dan densitas dari sampel. Pengujian kadar air dilakukan berdasarkan SNI 1965 : 2008 dan dimaksudkan untuk mengetahui persentase kandungan air dalam material tanah ${ }^{(14)}$. Penentuan kadar air dihitung berdasarkan persamaan 1 .

$$
\mathrm{w}=\frac{\mathrm{W}_{1}-\mathrm{W}_{2}}{\mathrm{~W}_{2}-\mathrm{W}_{3}} \times 100 \%
$$

Keterangan :

$\begin{array}{ll}\mathrm{W} & =\text { kadar air }(\%) \\ \mathrm{W}_{1} & =\text { berat cawan dan tanah basah (gram) } \\ \mathrm{W}_{2} & =\text { berat cawan dan tanah kering (gram) } \\ \mathrm{W}_{3} & =\text { berat cawan (gram) } \\ \left(\mathrm{W}_{1}-\mathrm{W}_{2}\right) & =\text { berat air (gram) } \\ \left(\mathrm{W}_{2}-\mathrm{W}_{3}\right) & =\text { berat tanah kering (gram) }\end{array}$

Pengujian densitas dari sampel dilakukan berdasarkan SNI 1743 : 2008 dan dimaksudkan untuk mengetahui berat kepadatan sampel per volume $^{(15)}$. Penentuan densitas basah dihitung berdasarkan Persamaan 2 dan penentuan densitas kering dihitung berdasarkan persamaan 3.

$$
\rho=\frac{B_{2}-B_{1}}{V} \ldots \ldots
$$

Keterangan:

$\rho=$ densitas basah $\left(\mathrm{g} / \mathrm{cm}^{3}\right)$

$\mathrm{B}_{1}=$ massa cetakan dan keping alas (gram)

$\mathrm{B}_{2}=$ massa cetakan, keping alas dan sampel (gram)

$\mathrm{V}=$ volume cetakan $\left(\mathrm{cm}^{3}\right)$

$$
\rho_{d}=\frac{\rho}{(100+w)} \times 100 \%
$$

Keterangan:

$$
\begin{aligned}
\rho_{\mathrm{d}} & =\text { densitas kering }\left(\mathrm{g} / \mathrm{cm}^{3}\right) \\
\rho & =\text { densitas basah }\left(\mathrm{g} / \mathrm{cm}^{3}\right) \\
\mathrm{w} & =\text { kadar air }(\%)
\end{aligned}
$$

Selanjutnya dilakukan uji penetrasi untuk mendapatkan kurva hubungan antara beban dan penetrasi dengan peralatan berupa cetakan, peralatan pembebaan, dan arloji ukur yang prosedurnya berdasarkan SNI 1744 : 2012. Gambar peralatan uji penetrasi disajikan dalam Gambar 2.
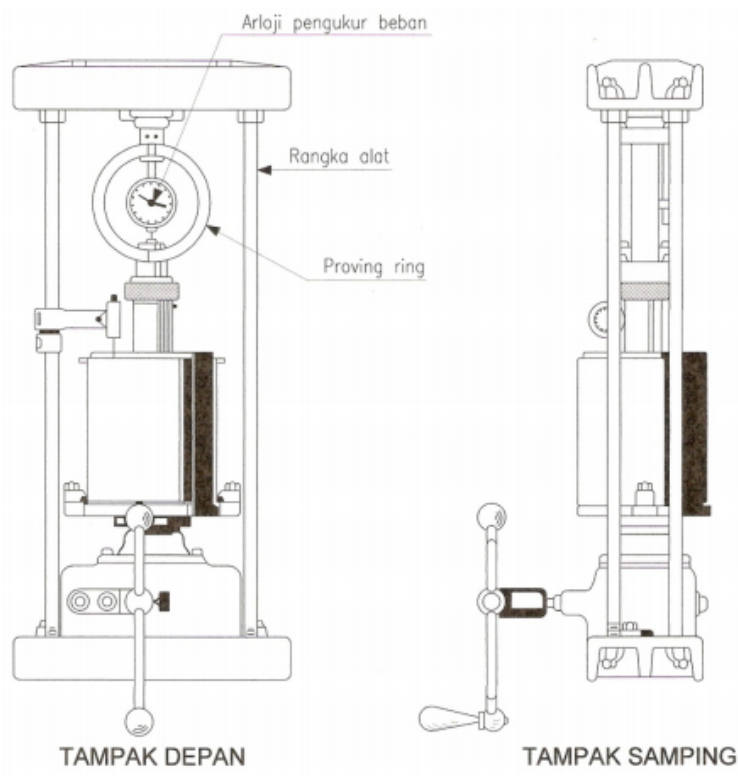

Gambar 2. Tipikal alat uji penetrasi laboratorium berdasar SNI 1744:2012

Nilai CBR sangat mempengaruhi besarnya daya dukung tanah, semakin besar CBR tanah maka semakin besar pula daya dukungnya. CBR juga menentukan dalam desain perkerasan jalan yang akan digunakan ${ }^{(16)}$. Pada umumnya nilai CBR tanah dasar dan tanah timbunan di Indonesia berkisar antara $2,5-7 \%$ dengan asumsi desain menggunakan nilai CBR sebesar $6 \%{ }^{(17)}$.

Penentuan nilai CBR dapat dilakukan secara langsung di lapangan dan juga di laboratorium. Prosedur penentuan nilai CBR di laboratorium dilakukan dengan uji penetrasi beban untuk mendapatkan kurva hubungan antara beban dan penetrasi dan penentuan besarnya CBR diperoleh berdasarkan nilai beban terkoreksi pada penetrasi $2,54 \mathrm{~mm}(0,1 \mathrm{inci})$ dan $5,08 \mathrm{~mm}$ $(0,2$ inci) yang dihitung dengan menggunakan Persamaan 4.

$$
\mathrm{CBR}=\frac{\text { Beban Terkoreksi }}{\text { Beban Standar }} \times 100 \% \ldots
$$


Nilai CBR dinyatakan dalam persen, diperoleh dengan cara membagi nilai beban terkoreksi pada penetrasi $2,54 \mathrm{~mm}$ dan $5,08 \mathrm{~mm}$ dengan beban standar dengan nilai $13 \mathrm{kN}$ dan $20 \mathrm{kN}$ dan dikalikan dengan 100. Nilai CBR umumnya dipilih pada penetrasi $2,54 \mathrm{~mm}$ (SNI $1744: 2012$ ).

\section{HASIL DAN PEMBAHASAN}

\subsection{Hasil Pengujian Kadar Air}

Pada penelitian ini kadar air tertinggi pada sampel ST03 dengan nilai 30,83\% dan terendah pada sampel ST05 dengan nilai $4,16 \%$. Tanah lempung asli variasi ST01 menghasilkan nilai $21,19 \%$. Penambahan CS-60 pada variasi ST02 dengan nilai $24,81 \%$ tidak menurunkan kadar air tanah lempung, namun dengan penambahan limbah SBE akan menurunkan kadar air, hal ini terlihat pada variasi sampel ST03, ST04, dan ST05, dengan kadar air berurutan 30,83\%, $15,33 \%$, dan $4,16 \%$. Hasil pengujian kadar air disajikan pada Gambar 3.

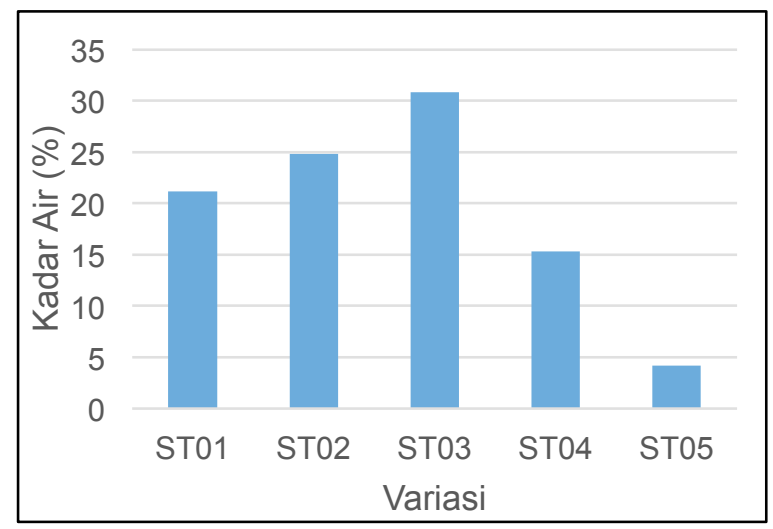

Gambar 3. Hasil pengujian kadar air

Dari beberapa penelitian sebelumnya tanah lempung asli memiliki kadar air berkisar antara $20-58 \%^{(18-20)}$. Bahan stabilisasi memberikan pengaruh menurunkan kadar air pada tanah asli, tanah yang memiliki kadar air lebih rendah akan lebih stabil bila dibandingkan dengan tanah dengan kadar air lebih tinggi. Hal ini ditunjukkan pada penelitian ini penggunaan SBE sebagai bahan stabilisasi tanah memberikan kadar air berkisar antara 4,16-30,83\% sehingga penggunaan SBE sangat optimal dalam menurunkan kadar air.

\subsection{Hasil Pengujian Densitas}

Berdasarkan hasil pengukuran nilai densitas pada penelitian ini diperoleh nilai densitas tertinggi pada variasi tanah lempung ST01 dengan nilai $1,086 \mathrm{~g} / \mathrm{cm}^{3}$ pada kondisi basah dan $0,896 \mathrm{~g} / \mathrm{cm}^{3}$ pada kondisi kering, di samping itu, densitas paling rendah pada variasi ST05 dengan nilai $0,216 \mathrm{~g} / \mathrm{cm}^{3}$ pada kondisi basah dan $0,208 \mathrm{~g} / \mathrm{cm}^{3}$ pada kondisi kering. Dari data pengujian densitas terlihat pula bahwa semakin banyak penambahan material SBE akan menurunkan nilai densitas dari variasi ST01 hingga ST05. Nilai densitas basah yang diperoleh pada ST01 hingga ST05 berurutan adalah $1,086 \mathrm{~g} / \mathrm{cm}^{3}, 0,727 \mathrm{~g} / \mathrm{cm}^{3}, 0,595 \mathrm{~g} / \mathrm{cm}^{3}$ $0,305 \mathrm{~g} / \mathrm{cm}^{3}, 0,216 \mathrm{~g} / \mathrm{cm}^{3}$, dan densitas kering yang diperoleh berurutan adalah $0,896 \mathrm{~g} / \mathrm{cm}^{3}$, $0,582 \mathrm{~g} / \mathrm{cm}^{3}, 0,454 \mathrm{~g} / \mathrm{cm}^{3}, 0,264 \mathrm{~g} / \mathrm{cm}^{3}$, dan $0,208 \mathrm{~g} / \mathrm{cm}^{3}$. Hasil pengujian densitas disajikan pada Gambar 4 .

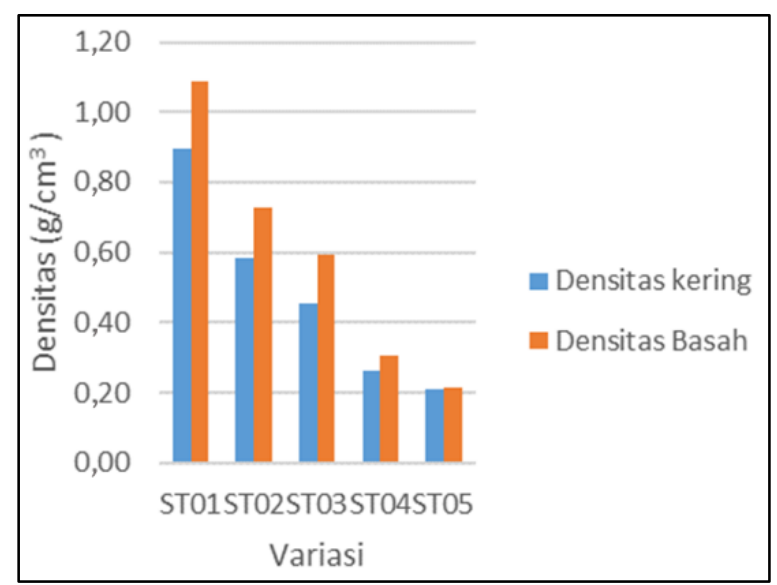

Gambar 4. Hasil pengujian densitas

Penggunaan material limbah pada stabilisasi tanah akan menurunkan densitas dari tanah asli, hal ini sesuai dengan penelitian terdahulu yang menggunakan material limbah dapat menurunkan densitas hingga $12,33 \%$ dari tanah lempung asli ${ }^{(21)}$. Semakin rendah densitas suatu material akan semakin baik karena akan membuat konstruksi semakin ringan dan semakin mudah dalam pelaksanaan proyek. Dengan demikian penggunaan SBE merupakan upaya menurunkan densitas, di mana pada penelitian ini SBE dapat menurunkan densitas sebesar $80,11 \%$ pada kondisi tanah basah dan $76,79 \%$ pada kondisi tanah kering.

Penggunaan SBE sebagai alternatif material dapat menurunkan densitas sehingga berat material menjadi lebih ringan. Hal tersebut dapat dilihat dari hasil penelitian ini SBE digunakan sebagai bahan alternatif dalam stabilisasi tanah. Hasil serupa juga diperoleh pada penelitian sebelumnya yang memanfaatkan SBE sebagai alternatif agregat halus dapat menurunkan berat hingga $17,47 \%$ pada mortar beton ${ }^{(22)}$. Dampak positif dengan material yang lebih ringan adalah akan mengurangi berat secara keseluruhan pada proses pelaksanaan pekerjaan. 


\subsection{Hasil Pengujian Penetrasi Beban dan Nilai CBR}

Berdasarkan pengujian penetrasi beban yang disajikan pada Gambar 5 menunjukkan bahwa semakin banyak penambahan SBE akan meningkatkan beban penetrasi bila dibandingkan dengan hanya menggunakan CS60 baik pada penurunan 0,1 inch maupun 0,2 inch. Nilai beban yang diperoleh pada penurunan 0,1 inci dari variasi ST01 hingga ST05 berurutan adalah 105,60 lb, 147,84 lb, $147,84 \mathrm{lb}, 253,44 \mathrm{lb}, 563,20 \mathrm{lb}$, dan pada penurunan 0,2 inci diperoleh nilai berurutan sebesar 133,76 lb, 228,80 lb, 264,00 lb, 387,20 $\mathrm{lb}$, dan $774,40 \mathrm{lb}$.

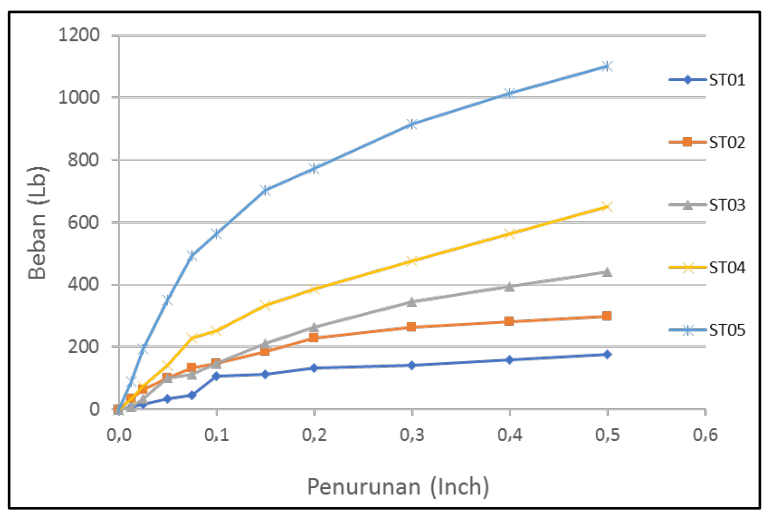

Gambar 5. Pengujian penetrasi beban

Dengan meningkatnya nilai beban penetrasi seiring dengan penambahan limbah SBE pada CS-60 10\%, akan meningkatkan nilai CBR yang diperoleh. Dari grafik yang disajikan pada Gambar 6 ditunjukkan bahwa nilai CBR terus meningkat pada variasi ST01 hingga ST05 dengan nilai CBR berurutan sebesar 3,24\%, $5,01 \%, 5,39 \%, 8,52 \%$, dan $17,99 \%$.

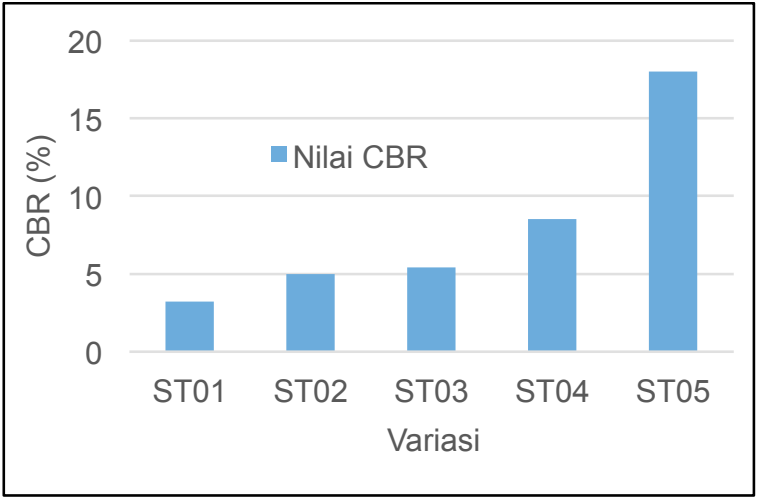

Gambar 6. Nilai CBR

Berdasarkan hasil pengujian, terlihat bahwa limbah SBE memiliki potensi yang sangat baik untuk dijadikan material alternatif pada stabilisasi tanah. Hal ini ditunjukkan dengan meningkatnya nilai CBR hasil pengujian. Sama seperti halnya pada penelitian terdahulu yang memanfaatkan SBE sebagai bahan alternatif pembuatan bata maupun batako ${ }^{(23,24)}$, di mana kekuatan yang baik diperoleh dengan memanfaatkan SBE hingga 25\%. Penggunaan SBE sebesar $10 \%$ pada campuran beton juga telah dinyatakan memenuhi kelayakan secara teknis dan lingkungan ${ }^{(25)}$. Nilai CBR yang peroleh pada penelitian ini dengan memanfaatkan SBE sebagai bahan stabilisasi berkisar antara 5,01-17,99\%. Nilai ini sesuai dengan standar CBR untuk tanah dasar dengan mutu sedang dan baik ${ }^{(26)}$

Berdasarkan hasil ini SBE sangat berpotensi sebagai alternatif bahan stabilisasi tanah dan diproyeksikan untuk digunakan secara massal dengan mudah karena langsung ditambahkan pada proses pelaksanaan stabilisasi tanah di lapangan tanpa ada instalasi peralatan khusus dalam pencampuran. Dengan demikian hasil penelitian ini semakin menambah potensi SBE sebagai alternatif material.

\section{KESIMPULAN}

Berdasarkan hasil dan analisis pada penelitian ini dapat dilihat densitas basah maupun kering pada tanah lempung akan menurun bila ditambahkan CS-60 dan juga limbah SBE. Semakin besar persentase limbah SBE yang ditambahkan maka densitas basah maupun keringnya akan menurun. Limbah SBE dapat digunakan sebagai bahan untuk stabilisasi tanah lempung, hal ini dikarenakan tanah lempung yang distabilisasi dengan CS-60 yang ditambah SBE lebih meningkatkan nilai CBR tanah bila dibanding hanya sekedar menggunakan CS-60 untuk stabilisasi.

Nilai CBR yang dihasilkan pada penelitian ini telah sesuai dengan standar manual desain perkerasan jalan di mana stabilisasi tanah dasar yang dihasilkan masuk dalam kategori mutu sedang dan baik. Hasil penelitian ini juga sangat mudah diaplikasikan pada proyek di lapangan dan ketersediaan bahan limbah SBE yang melimpah sehingga SBE memiliki potensi sebagai material alternatif untuk bahan stabilisasi dan sebagai solusi untuk mengurangi jumlah limbah.

Penelitian ini dapat terus dilanjutkan dengan mengkaji kemungkinan SBE mengalami pelindian (leaching) ke lingkungan dan durabilitasnya jika diaplikasikan di lapangan.

\section{PERSANTUNAN}

Terima kasih kepada saudara Ardi yang telah membantu dalam pengujian di laboratorium Teknik Sipil Universitas Mercubuana. 


\section{DAFTAR PUSTAKA}

1. Palar, H., Monintja, S., Turangan, A. E., Sarajar, A. N. (2013). Pengaruh Pencampuran Tras dan Kapur pada Lempung Ekspansif Terhadap Nilai Daya Dukung. Jurnal Sipil Statik. 1 : 390-399.

2. Daulay, M. (2013). Pengaruh Penambahan Clean Set Cement (CS-60) pada Stabilisasi Tanah Gambut Terhadap Parameter Kuat Gesernya. Proceeding $1^{\text {st }}$ International Conferenceon Infrastructure Development. p: 37- 42.

3. Ibrahim. (2014). Stabilisasi Tanah Lempung Dengan Bahan Aditif Fly Ash Sebagai Lapisan Pondasi Dasar Jalan (Subgrade). Pilar Jurnal Teknik Sipil. $10: 1-9$

4. Herfiantino, E., Yakin, Y.A. (2016). Perbaikan Tanah Untuk Meningkatkan CBR Dengan Bahan Aditif Serbuk Bata Merah Dan Abu Sekam Padi. Reka Racana Jurnal Online Institut Teknologi Nasional. 2:1-11.

5. Wagrakdiskul, U., Khonkaew, P., \& Wongchareonsin,T. (2014). Use of the Spent Bleaching Earth from Palm Oil Industry in Non Fired Wall Tiles. Proceeding International Symposiumonthe Fusion Technologies.p : 110.

6. Sumarno, A., Widodo, E., Nugroho, A., Triastuti \& Suryanegara, L. (2017). Pemanfaatan Limbah Spent Bleaching Earth (SBE) Dari Industri Pengolahan Minyak Kelapa Sawit Pada Aplikasi Bata Beton. Prosiding Seminar Lignoselulosa 2017.p:4246.

7. Fattah, R. A., Mostafa, N. A., Mahmoud, M.S., \& Abdelmoez, W. (2014). Recovery of oil and free fatty acids from spent bleaching earth using sub-critical water technology supported with kinetic and thermo dynamic study. Advances in Bioscience and Biotechnology. 5:261-272.

8. Nasution,E, Z. (2003). Manfaat Dari Beberapa Jenis Bleaching Earth Terhadap Warna CPO (Crude Palm Oil). Jurnal Sains Kimia. 7(2).p: 31-35.

9. Suryani, A., Pari, G., \& Aswad, A. (2013). Proses Reaktivasi Spent Bleaching Earth Sebagai Adsorben Untuk Pemurnian Biodisel dan Crude Palm Oil.Prosiding Seminar Tahunan Maksi 2013.p :274-296.

10. Krisyanti, S. \& Sukandar. (2011). Recovery Minyak Dari Limbah Bahan Berbahaya dan Beracun (B3) Spent Bleaching Earth dengan Metode Ekstraksi Pelarut. Jurnal Teknik Lingkungan. $17: 35-46$.
11. Ashari, M, L., Dermawan, D. \& Sunarya, R, B. (2017). Pemanfaatan Limbah Padat Spent Bleaching Earth pada PT. SMART Tbk Surabaya Sebagai Pengganti Agregat Halus Pada Campuran Beton. Seminar MASTER 2017 PPNS. P : 123-128.

12. Wachira J. Muthengia, wa-Thiong'o J. Karanja, Gerald K. Muthakia. (2005). Spent Bleaching Earth as a Pozzolanic Materials. Journal of Civil Engineering Research and Practice. 2(1).

13. Badan Standarisasi Nasional. (2012). Metode Uji CBR Laboratorium. SNI 1744 : 2012. Jakarta : BSN.

14. Badan Standarisasi Nasional. (2008). Cara uji penentuan kadar air untuk tanah dan batuan di laboratorium. SNI 1965 : 2008. Jakarta : BSN.

15. Badan Standarisasi Nasional. (2008). Cara Uji Kepadatan Ringan untuk Tanah. SNI 1743 : 2008. Jakarta : BSN.

16.Akbar, S. J. (2013). Kajian Pengaruh Nilai CBR Subgrade Terhadap Tebal Pekerjaan Jalan. Teras Jurnal. $3: 138-147$.

17.Kementerian Pekerjaan Umum. (2013). Manual Desain Perkerasan Jalan. Jakarta.

18. Mina, E., Kusuma, R, I.,\& Subowo, I, S, L. (2016). Pengaruh Fly Ash Terhadap Nilai CBR dan Sifat-Sifat Propertis Tanah. Jurnal Fondasi. 5(2). p : 40-50.

19. Andriani., Yuliet, R.,\& Fernandez, F, L. (2012). Pengaruh Penggunaan Semen Sebagai Bahan stabilisasi Pada Tanah Lempung Daerah Lambung Bukit Terhadap Nilai CBR Tanah. Jurnal Rekayasa Sipil. 8(1). p: 29-44.

20. Mawardi., Razali, M,R ., \& Wijaya, O. (2016). Nilai CBR Pada Stabilisasi Tanah Dengan Semen Jalan Budi Utomo UNIB Depan. Jurnal Inersia. 8(2). p: 67-75.

21. Ningrum, P., Nugroho, S, A \& Muhardi. (2014). Pengaruh Penambahan Air Diatas Kadar Air Optimum Terhadap Nilai CBR Dengan dan Tanpa Rendaman Pada Tanah Lempung Yang dicampur Abu Terbang. Jom FTEKNIK. 1(2). $p: 1-7$

22. Sumarno, A., Widodo, E., Triastuti\& Nugroho, A. (2018). Pengaruh Waktu Curing Terhadap Kuat Tekan Mortar Semen dengan Limbah Spent Bleaching Eearth (SBE) Sebagai Subsitusi Agregat Halus. Prosiding Seminar Lignoselulosa 2018.p:58-62.

23. Pojoh, B. \& Ola, A, L. (2016). Penanganan Tumpukan Limbah Spent Bleaching Earth Pabrik Minyak Kelapa Melalui Pembuatan 
Batako. Jurnal Penelitian Teknologi Industri. 8 : 1-10.

24. Abrar, A.\& Abdillah, N. (2019). Studi Eksperimen Pemanfaatan Limbah Spent Bleaching Earth (SBE) Sebagai Bahan Pembuatan Bata. Siklus Jurnal Teknik Sipil. 5 : 70-78.

25. Ashari, M, L. \& Dermawan, D. (2018). Studi Pemanfaatan Limbah Padat Industri Pengolahan Minyak Kelapa Sawit Spent Bleaching Earth Sebagai Pengganti Agregat
Pada Campuran Beton. Jurnal Presipitasi Media Komunikasi dan Pengembangan Teknik Lingkungan. $15: 7-10$.

26. Kusuma, R, I., Mina, E., Fathonah, W., \& Kartika, C, D. (2020). Stabilisasi Tanah Lempung Organik Menggunakan Semen Slag Terhadap Nilai CBR Berdasarkan Variasi Kadar Air Optimum (Studi Kasus Jl. Raya Kubang Laban, Desa Terate, Kecamatan Kramatwatu, Kabupaten Serang). Jurnal Fondasi. 9(2).p : 154-164. 